\title{
Justice Brennan, Equality, and Majority Rule
}

\section{Citation}

Mark Tushnet Justice Brennan, Equality, and Majority Rule, 139 U. Pa. L. Rev. 1357 (1991).

\section{Published Version}

http://scholarship.law.upenn.edu/penn_law_review/vol139/iss5/6/

\section{Permanent link}

http://nrs.harvard.edu/urn-3:HUL.InstRepos:12918344

\section{Terms of Use}

This article was downloaded from Harvard University's DASH repository, and is made available under the terms and conditions applicable to Other Posted Material, as set forth at http:// nrs.harvard.edu/urn-3:HUL.InstRepos:dash.current.terms-of-use\#LAA

\section{Share Your Story}

The Harvard community has made this article openly available.

Please share how this access benefits you. Submit a story.

\section{Accessibility}




\section{JUSTICE BRENNAN, EQUALITY, AND MAJORITY RULE}

\section{MARK TUSHNET $\dagger$}

From the beginning of his service on the Supreme Court to the end, Justice Brennan dealt with the issues of equality that have pervaded the development of the social order in the United States and that have therefore pervaded constitutional law. His opinions on these issues covered a wide range and contained many themes. Here I want to extract a single theme from the complex jurisprudence of equality that Justice Brennan articulated-the theme of "majoritarian egalitarianism," to give it a label that Justice Brennan would never use. After describing the way in which some of Justice Brennan's opinions reflected majoritarian egalitarianism, I suggest that the theme reflects a deeply attractive optimism about the state of our society, an optimism entirely compatible with the Justice's character. ${ }^{1}$

Today, so soon after Justice Brennan's resignation, it is almost conventional to note that his last opinion for the Court upheld an affirmative action program. ${ }^{2}$ Metro Broadcasting, Inc. v. Federal Communications Commission 3 involved two "minority preference policies" adopted by the Commission. Justice Brennan's opinion for the Court dealt with many topics: It adopted a standard of review for certain affirmative action programs, it endorsed "diversity" as a permissible goal of federal action, and it rejected the argument that stereotypes alone explained why the Commission believed that minority preference policies would promote diversity. ${ }^{4}$

† Professor of Law, Georgetown University Law Center.

1 I must note that I do not suggest that this single theme reconciles all of Justice Brennan's opinions dealing with equality, or even that all of them express this theme, or are at least consistent with it. I suspect that anyone's work over a period of over thirty years would contain inconsistencies, and I have not canvassed Justice Brennan's entire corpus to see if majoritarian egalitarianism is even a dominant theme in his opinions. My claim is only that this theme can be found in a number of important cases and that its presence sheds light on Justice Brennan's work and character.

${ }^{2}$ See Metro Broadcasting, Inc. v. FCC, 110 S. Ct. 2997 (1990). I suspect that, as the events recede, the convention will change and another Brennan opinion about equality will come to open commentators' and historians' discussions. At this point, though, there is no telling which opinion that would be.

3 Id.

1 For a discussion of these and other aspects of the opinion, see Williams, Metro Broadcasting, Inc. v. FCC: Regrouping in Singular Times, 104 HARV. L. REV. 525 (1990). 
Here I want to focus on only one facet of the case. Although the Commission initially had adopted the minority preference policies, the Court analyzed them as if they were embodied in statutes adopted by Congress. For the Court, the fact that the policies were "specifically approved-indeed, mandated-by Congress" was a fact of "overriding significance."

Congressional approval was important for several reasons. First, on the level of "court watching," many observers counted heads and put Justice White in the camp of opponents of affirmative action, on the basis of his opinion for the Court in Wards Cove Packing Co. $v$. Atonio ${ }^{6}$ and his vote against Richmond's affirmative action program in City of Richmond v. J.A. Croson Co. ${ }^{7}$ These observers overlooked Justice White's even deeper commitment to the affirmative use of national power in the service of goals of racial equality, as determined by Congress itself. For Justice White to join the majority, then, it was important to stress that Congress, not the Commission, adopted the minority preferences.

It is too easy, and almost too cheap, to attribute Metro Broadcasting's emphasis on Congress to Justice Brennan's ability to build coalitions. After all, there was a good reason grounded in existing doctrine for making congressional approval crucial. ${ }^{8}$ The Richmond affirmative action case held unconstitutional a "set aside" program that reserved a portion of the city's construction budget for minority contractors. ${ }^{9}$ The Supreme Court had upheld a federal set aside program, on which the Richmond one was modelled, in Fullilove $v$. Klutznick. ${ }^{10}$ In rejecting the city's effort to rely on Fullilove, the Court in the Richmond case distinguished

${ }^{5} 110$ S. Ct. at 3008 . The Commission adopted the policies in 1978. Id. at 3004. After the Commission's membership changed as a result of the election of Ronald Reagan, it began an inquiry into whether the policy should be maintained. In 1988, Congress responded by barring the Commission from spending any money to examine or change the policies. Siee id. at 3006.

6109 S. Ct. 2115 (1989).

7488 U.S. 469 (1989).

${ }^{8}$ I have discussed Justice Brennan's ability to build a coalition to support a result surprising to outsiders in Tushnet, The Optimist's Tale (Book Review), 132 U. PA. L. REV. 1257, 1263-65 (1984). In my defense, my primary evidence there involved Justice Brennan's invocation of an idiosyncratic theory, adhered to almost exclusively by Justice Stevens, about the relative roles of state and national governments in regulating incidents of the status of aliens. In Metro Broadcasting, in contrast, the doctrine on which Justice Brennan relied recently had been adopted by a majority of the Court.

9488 U.S. at 511.

${ }^{10} 448$ U.S. 448 (1980). 
between the power of the national government to adopt affirmative action programs and the power of state and local governments to do so. The difference, according to the Court, was that section five of the fourteenth amendment specifically gave Congress power to enforce the guarantees of equal treatment embodied in section one of that amendment, whereas section one itself limited the power of states to deal with issues of race. ${ }^{11}$

Considered in light of general assumptions about state governments, the J.A. Croson Court's distinction is quite remarkable. Though rooted in Katzenbach $v$. Morgan, ${ }^{12}$ the distinction is difficult to sustain as a textual matter. According to the Court in $J . A$. Croson, the city's affirmative action program violated the guarantee in section one of the fourteenth amendment of equal protection of the laws. ${ }^{13}$ Consider an identical affirmative action program adopted by Congress. Section five gives Congress the power to "enforce . . . the provisions" of section one. ${ }^{14} \mathrm{But}$, if the affirmative action program in substance violated section one, the sense in which an identical federal program "enforces" section one is, to say the least, quite peculiar.

Even more remarkable, the Court's distinction in J.A. Croson contradicts basic assumptions about the structure of the government. The standard view divides the constitutional order into two parts: powers and restrictions. State governments, it is ordinarily held, have general legislative authority, subject solely to restrictions placed on them by the Constitution, whereas the national government is a government of enumerated powers. As a government of enumerated powers, the national government cannot have more power than state governments, though the states might be restricted in ways that the national government is not. Yet, according to $J . A$. Croson, section five is a sort of "super"-power, giving the national government the power to do things that state governments cannot. ${ }^{15}$

11488 U.S. at $490-91$.

12384 U.S. 641, 651 (1966) ("Correctly viewed, $\$ 5$ is a positive grant of legislative power authorizing Congress to exercise its discretion in determining whether and what legislation is needed to secure the guarantees of the Fourteenth Amendment.").

13488 U.S. at 511.

14 U.S. CONST. amend. XIV, \$5.

15 One might try to rescue J.A. Croson along the following lines, not developed by the Court. Section one is a restriction on the power of state governments. The national government is not subject to a similar restriction. It may therefore exercise any of its enumerated powers to adopt programs that states are barred from adopting by section one. Two difficulties with this reconstruction are apparent. First and less important, although section five played a seemingly important part in the Court's 
Metro Broadcasting simply took the distinction seriously. Justice Brennan might have been tweaking the conservatives for having attempted disingenuously to preserve Fullilove while actually gutting its rationale. There is a reason, though, beyond text and structure, for the distinction between national and state powers over issues implicating race. As Justice Scalia pointed out in J.A. Croson, the Madisonian theory of the national government holds that it is less likely to be dominated by self-serving factions and is more likely to take a wider view of the public interest than state and local governments are. ${ }^{16}$

Taking this functional view of the distinction, we can see how Metro Broadcasting is a decision involving majoritarian egalitarianism. According to Justice Brennan's opinion for the Court, because a majority of the people of the United States, acting through their representatives, have determined that minority preference programs serve egalitarian goals, their decision should be upheld. ${ }^{17}$

Majoritarian egalitarianism helps make sense of an otherwise puzzling passage in Frontiero $v$. Richardson, ${ }^{18}$ in which Justice Brennan tried to persuade the Court to declare that gender was a "suspect classification." ${ }^{19}$ The case involved the constitutionality of a federal statute that awarded spousal benefits to male servicemen but required female members of the armed forces to demonstrate that their spouses were dependent on them before they could receive spousal benefits. ${ }^{20}$ Although Justice Brennan was inclined to find sex a suspect classification and told his colleagues that he would like to do so, he first circulated an opinion saying that the distinction embodied in the statute was simply arbitrary. ${ }^{21}$ Yet,

analysis in J.A. Croson, it drops out entirely of the reconstruction. Second, Bolling v. Sharpe, 347 U.S. 497,500 (1954), at least in the context of school segregation, held that it would be "unthinkable" to subject the national government to lesser restrictions than state governments.

${ }^{16} 488$ U.S. at $522-23$ (Scalia, J., concurring in the judgment).

17 The statement in the text short-circuits the rest of the Court's opinion, which applied a "standard of review" to decide that the minority preference programs were permissible. See $110 \mathrm{~S}$. Ct. at 3008-09. For the purposes of this essay, the "standard of review" and its application are unimportant. For a discussion of the degree of deference Justice Brennan's opinion paid to the majority's conclusion that the minority preference programs did indeed serve egalitarian goals, see infra text accompanying notes $\mathbf{3 1 - 3 4}$.

18411 U.S. 677 (1973).

19 Id. at $682-88$.

$20 \mathrm{Id}$. at $678-79$.

21 The facts recounted here are drawn from B. SCHWARTZ, THE UNPUBLISHED OPINIONS OF THE BURGER COURT 65-82 (1988), although my interpretation of the 
because the statute was founded on the undoubted fact that more wives of servicemen were dependent on them than were husbands of servicewomen on their spouses, the use of that standard would substantially alter existing understandings of what "arbitrary" meant. Prodded by Justice White, and consistent with his initial desires, Brennan recirculated a draft saying that gender was a suspect classification. ${ }^{22}$

The redraft failed to gain a majority, but it appeared in substantially unaltered form as the opinion of a plurality of the Court. ${ }^{23}$ After discussions of the history of discrimination against women and of the immutability of gender, the opinion found support for its conclusion in congressional action. Justice Brennan mentioned the prohibition on sex discrimination in Title VII of the Civil Rights Act of 1964 and, more controversially, the submission of the Equal Rights Amendment to the states. ${ }^{24}$ On the surface, this is surprising. Declaring sex a suspect classification would have accomplished almost everything that adopting the Equal Rights Amendment would. Yet, because the amendment had only been submitted to the states but not ratified, Justice Brennan's position seems to be that Congress effectively can amend the Constitution itself. Congress merely needs to submit an amendment to the states and then ask the Court to take the submission of the amendment as an indication of a majority's views on a matter of constitutional dimension. As Justice Powell put it in an opinion concurring in the result: "[T]he Court has assumed a decisional responsibility at the very time when state legislatures, functioning within the traditional democratic process, are debating the proposed Amendment. ${ }^{25}$

Justice Brennan's position in Frontiero, however, is less strange than it initially appears. In a number of contexts, the Court has relied on majoritarian disapproval of a practice to establish its unconstitutionality. For example, in finding unconstitutional the imposition of the death penalty on an offender who was under fifteen years old at the time he committed murder, the Court relied in part on the widespread but not universal judgment that capital punishment was inappropriate in such cases. ${ }^{26}$

state of the law differs from Schwartz's.

${ }^{22}$ See id. at 78-79.

23 See id. at 81 .

24411 U.S. at 687.

25 Id. at 692 (Powell, J., concurring in the judgment).

${ }^{26}$ See Thompson v. Oklahoma, 487 U.S. 815, 821-33 (1988). 
By making such decisions, the Court does two things that deserve note. First, it pushes the society further in the direction it was already moving. One might think of the Court as cleaning up some matters that had fallen by the wayside as the majority of the society moved on. Second, it transforms an existing majority's views about sound policy into a constitutional mandate. One might worry that the Court could get things wrong. Conceivably, it might detect a movement in a "progressive" direction (however defined) and constitutionalize it, thereby' making it impossible for the society to change course. That fear, though, is overstated. If the Court "got it wrong" and the society came to want to change course, at some point the composition of the Court would change too, and a new majority on the Court would unfreeze the situation.

Consider here the aftermath of Frontiero. The Equal Rights Amendment was not ratified, yet Justice Brennan correctly perceived general social support for a principle of gender equality. Suppose the Court had adopted Justice Brennan's position in 1973. Thereafter the test applied in cases of gender discrimination would have been strict scrutiny rather than intermediate scrutiny, as it is now. Would the cases since 1973 have come out differently under strict scrutiny?

Answering such a question obviously invites controversy. Deciding whether some statute survives the prescribed level of scrutiny is an exercise in judgment, and judgments will vary. Most commentators believe that the Court did something unusual when it invalidated a zoning reggulation in City of Clebume v. Clebume Living Center, ${ }^{27}$ using the lowest level of review for a "rational basis." ${ }^{28}$ At the other end of the scale, Justice O'Connor suggested in J.A. Croson that a set aside program could satisfy strict scrutiny if it was designed to "break down patterns of deliberate exclusion" of minority contractors from subcontracting. ${ }^{29}$ This is at least a slight modification of the usual understanding that strict scrutiny is "strict' in theory and fatal in fact." ${ }^{\text {"O }}$ The point is that circumstances affect what counts as satisfying any prescribed level of review.

${ }^{27} 473$ U.S. 432 (1985).

${ }^{28} \mathrm{Id}$. at $446-50$.

${ }^{29} 488$ U.S. at 509.

${ }^{30}$ Gunther, The Supreme Court, 1971 Term-Foreword: In Search of Evolving Doctrine on a Changing Court: A Model for a Newer Equal Protection, 86 HARV. L. REV. 1, 8 (1972). 
Had the Court adopted strict scrutiny for gender classifications, and had the Equal Rights Amendment failed, I wonder whether strict scrutiny for gender classifications would mean the same thing that it might have meant to Justice Brennan in 1973. I suspect that it would not-that, in light of the society's understandings as reflected in the failure of the Equal Rights Amendment, strict scrutiny for gender classifications would look a lot like intermediate scrutiny does today.

The preceding analysis connects the majoritarian egalitarianism of Frontiero and Metro Broadcasting. Both cases involve two kinds of confidence. First, in both Justice Brennan expresses confidence in the judgment of the people of the United States: The Court stressed that the "conclusion of a coequal branch of Government" that classifications based on sex were "inherently invidious ... is not without significance, ${ }^{n 31}$ and Congress's decision to mandate the minority preferences had "overriding significance." 32

Second, in both cases Justice Brennan expresses, more subtly, confidence in the Court's ability to detect when a majority's decision is indeed egalitarian in a constitutional sense and when it is either merely a policy preference or actually inegalitarian. Justice Kennedy's dissent in Metro Broadcasting put the question to Justice Brennan quite sharply. Suppose we do defer to majoritarian judgments about what best promotes egalitarian goals. Justice Kennedy pointed out that, at least since the rise of majoritarian democracy, defenders of inequality routinely have defended their proposals as "truly" promoting equality in the long run. ${ }^{33}$ In retrospect, of course, we have concluded that segregation did not promote equality, but in the midst of the battle how are we to know whether a racial classification is benign (egalitarian) or invidious (inegalitarian)? Justice Brennan responded in a footnote, saying that the Court was "confident" that it could "separate benign measures from other types of racial classifications. ${ }^{\text {"34 }}$ The source of his confidence, though, was not spelled out, and a skeptic might point out that anyone adopting Justice Brennan's view would almost inevitably be confident in his or her ability to make the very judgments that Justice Kennedy tried to bring into question.

\footnotetext{
${ }^{31} 411$ U.S. at $687-88$.

$32110 \mathrm{~S}$. Ct. at 3008.

33110 S. Ct. at 3044-46 (Kennedy, J., dissenting).

34 Id. at 3008 n.12.
} 
A similar confidence characterizes Justice Brennan's opinion for the Court in Baker v. Carr. ${ }^{35}$ The issue was whether voters could challenge legislative apportionments on the ground that vote dilution violated the equal protection clause. Most of the opinion deals with the political questions doctrine. For my purposes, the relevant criterion is that cases present political questions if there are no "judicially discoverable and manageable standards for resolving" them. ${ }^{36}$ But, said Justice Brennan, there were judicially manageable standards in apportionment cases: "Judicial standards under the Equal Protection Clause are well developed and familiar, and it has been open to courts since the enactment of the Fourteenth Amendment to determine . . . that a discrimination reflects no policy, but simply arbitrary and capricious action. ${ }^{37}$

As it turned out, the Court moved rapidly from this "no policy" position to "one person, one vote," as was almost certainly inevitable. ${ }^{38}$ The "one person, one vote" standard has numerous attractions. It captures the central, though not the only, social meaning of the vote in our society. Any other policies that apportionment might reflect could not yield the judicially manageable standards that Justice Brennan asserted were "well developed and familiar." In many ways, the very flatness of Justice Brennan's discussion of the equal protection clause in Baker is its most striking aspect. It is all so obvious, the opinion seems to say. As indeed it is, to one who is confident in the ability of the courts to discover what the people of the country really prefer.

Metro Broadcasting expresses Justice Brennan's majoritarian egalitarianism at the end of his time on the Court. Cooper $v$. Aaron, ${ }^{40}$ the Little Rock school case, exposes another facet of that commitment, near the beginning of his service on the Court. The opinion in Cooper was signed by all the Justices, at the suggestion of Justice Harlan, but Justice Brennan was the principal drafter. ${ }^{41}$

${ }^{35} 369$ U.S. 186 (1962).

${ }^{36} \mathrm{Id}$. at 217.

${ }^{37} I d$. at 226.

${ }^{38}$ See Reynolds v. Sims, 377 U.S. 533 (1964).

${ }^{39}$ Justice Harlan's dissent in Reynolds listed the following as among the permissible elements in apportionment: history, group interests, area, geography, sparse settlement, occupation, and balancing urban and rural power. Id. at 622-23 (Harlan, $J$., dissenting). If they are, Baker v. Carr was wrong, for there appears to be no way to transform them, or any similar list, into a judicially manageable standard. Harlan, of course, dissented in Baker. Set 369 U.S. at 330-49 (Harlan, J., dissenting).

${ }^{40} 358$ U.S. 1 (1958).

${ }^{41}$ See B. SCHWARTZ, SUPER ChIEF: EARL WARREN AND hIS SUPReme COURT-A 
The Court's opinion opened with a vigorous statement, drafted by Justice Black, that the case "raises questions of the highest importance to the maintenance of our federal system of government," because "[i]t necessarily involves a claim by the Governor and Legislature of a State that there is no duty on state officials to obey federal court orders resting on this Court's considered interpretation of the United States Constitution. ${ }^{42}$ The core of the opinion described what Justice Brennan called "some basic constitutional propositions" 43 to refute the premise that Arkansas's governor, Orval Faubus, was not bound by the Court's holding in Brown $v$. Board of Education. ${ }^{44}$ Because the Constitution was the "supreme Law of the Land, ${ }^{n 4}$ and because the Supreme Court had the power to "say what the law is," judiciary is supreme in the exposition of the law of the Constitution." ${ }^{27}$ As a result, the Court's interpretation of the Constitution in Brown had "binding effect" on state officials like Governor Faubus. ${ }^{48}$ "No state legislator or executive or judicial officer can war against the Constitution without violating his undertaking to support it." ${ }^{49}$ The opinion concluded by stating that "the obedience of the States to [the principles announced in Brown] ... are indispensable for the protection of the freedoms guaranteed by our fundamental charter for all of us. Our constitutional ideal of equal justice under law is thus made a living truth. ${ }^{50}$

Unlike Metro Broadcasting and Frontiero, Cooper does not deal directly with the substantive law of equality. Its commitment to one version of the rule of law, however, is an important complement to Justice Brennan's vision of a majoritarian egalitarianism. By insisting that the rule of law demands compliance with the Supreme Court's interpretation of the Constitution, Cooper ties together majoritarianism and the egalitarianism Justice Brennan would have the Court articulate. The people of the United States, that is, have

JUDICIAL BIOGRAPHY 295-301 (1983); Letter from Justice Harlan to Justice Brennan (Sept. 23, 1958) (Earl Warren Papers, Library of Congress, Box 584, file: Cooper v. Aaron).

12358 U.S. at 4.

43 Id. at 17 .

14347 U.S. 483 (1954).

45358 U.S. at 18 (quoting U.S. CoNST. art. VI).

${ }^{16} I d$. (quoting Marbury v. Madison, 5 U.S. (1 Cranch) 137, 177 (1803)).

${ }^{17} \mathrm{Id}$.

${ }^{48} I d$.

${ }^{49} \mathrm{Id}$.

${ }^{50} \mathrm{Id}$. at $19-20$. 
a fundamental commitment to the rule of law, which, in Justice Brennan's view, serves their long-term interest. Sometimes judicial review requires the Court to overturn decisions made by a temporary majority or, as in the segregation cases, by a geographically concentrated majority whose views the Court hoped were rejected by the people of the country as a whole. The "rule of law" commitment allows the Court to act on behalf of the permanent or national majority. The vigor of the Court's assertion that the rule of law required compliance with the necessary implications of Brown itself made the point that Brown was what the nation wanted, no matter what Governor Faubus and other opponents of desegregation believed.

This vision of the rule of law helps explain a practice by Justice Brennan that some critics argued was inconsistent with his position in Cooper. After the Court upheld the constitutionality of the death penalty under properly defined statutes, Justices Brennan and Marshall adopted the policy of dissenting whenever the Court denied review in a death peralty case. In over 1400 cases, they entered a dissent stating: "Adhering to our views that the death penalty is in all circumstances cruel and unusual punishment prohibited by the Eighth and Fourteenth Amendments, we would grant certiorari and vacate the death sentence in this case. ${ }^{51}$ Some critics called this practice "lawless. ${ }^{52}$

On the surface, the tension between Justice Brennan's position in the death penalty cases and Cooper is apparent. A majority of the Court has decided that, contrary to Brennan, the death penalty is not cruel and unusual punishment. The Court in Cooper asserted that all officials had a duty to follow the Constitution as interpreted by the Court. Brennan, therefore, should have taken the constitu-

51 See, e.g., Benner v. Ohio, 110 S. Ct. 1834, 1834 (1990) (citation omitted) (Brennan, J., and Marshall, J., dissenting).

52 For a version of the criticism, see L. LEVY, ORIGINAL INTENT AND THE FRAMERS' CONSTTIUTION 372-73 (1988):

What makes this humane opinion so arrogant is that Brennan knows that the Fifth Amendment three times assumes the legitimacy of the death penalty as does the Fourteenth Amendment .... Moreover, he also understands that a majority of his countrymen and his fellow Justices disagree with his opinion ... . No one has a right to veto the Constitution because his moral reasoning leads him to disagree with it in so clear a case. Brennan and Thurgood Marshall corrupt the judicial process and discredit it.

See also Mendelson, Brennan's Revolution, CommentaRY, Feb. 1991, at 36. 
tionality of the death penalty as a given and attempted faithfully to apply the eighth amendment doctrine the Court had developed.

Further, the Brennan position seems to be related to the position taken by then Attorney General Edwin Meese that the Constitution, rather than its interpretation by the Supreme Court, is the law of the land to which officials must adhere. ${ }^{53}$ Brennan appears, like Meese, to have been asserting that he was permitted to act on his own views of the Constitution notwithstanding the Court's interpretation of the document. Yet, many liberal supporters of Justice Brennan severely criticized Meese's position as a license for anarchy. ${ }^{54}$

When Meese's position is properly understood, it is less radical in its implications than his critics contended, and the position taken by Justice Brennan is consistent with a proper understanding of the relationship between the Constitution as supreme law and the Court's interpretations as supreme law. There are many situations in which officials can act on their own interpretations of the Constitution even if those interpretations differ from the Court's. For example, a legislator can refuse to vote for a statute that, as he or she sees it, would violate the Constitution, even if it is clear that the Court would uphold the statute.

Cooper is different, though, in one crucial respect: It is difficult to conceive of a lawsuit in which the legality of the legislator's actions could be tested. In contrast, in Cooper Governor Faubus could have been enjoined from interfering with the process of desegregation in Little Rock. In such a lawsuit, Faubus would have asserted that the Constitution allowed him to do so because, in his judgment, the Constitution permitted segregation despite what the Supreme Court had said in Brown. Faubus's defense would have been rejected, of course, but does his willingness to submit to an order against him, at the conclusion of extended litigation, justify his resistance to Brown until then? Probably not. Faubus, knowing how the litigation would certainly turn out, acted improperly in refusing to adhere to the Constitution as interpreted by the Supreme Court. ${ }^{55}$ Faubus's actions were improper, though, not

${ }^{53}$ See Meese, The Law of the Constitution, 61 TUL. L. REV. 979, 983 (1987).

${ }^{54}$ For a sampling of reactions to Meese, see Tushnet, The Supreme Court, the Supreme Law of the Land, and Attomey General Meese: A Comment, 61 TUL. L. REV. 1017,1017 n.1 (1987).

55 That the end result was certain is important to the analysis. If Faubus reasonably could have claimed that, because of changes in the composition of the Supreme Court, Brown might be reversed, he would not have acted improperly in 
because of some fundamental principle that officials must adhere to the Constitution as interpreted by the Court, but because in the circumstances his actions were unlikely to yield any social good and were highly likely to produce substantial social turmoil, as indeed they did. In short, officials are obliged by law to follow the Constitution, not the Supreme Court, but quite often they are obliged by prudence to follow the Supreme Court.

Justices of the Supreme Court are in a different position from other officials. They, too, are limited by prudence, but the consequences of their actions are different from those of governors or legislators. For a Justice to take a principled stand in dissenting from a denial of review in a death penalty case is, from that Justice's point of view, to adhere to the Constitution as supreme law, with essentially none of the consequences about which a prudent official ought to worry. ${ }^{56}$

For Justice Brennan, then, the prudent exercise of power undergirded the rule of law and made a stable social order possible. By making prudence and stability central to his vision of the Constitution, Justice Brennan avoided anxiety about the purportedly countermajoritarian character of judicial review. ${ }^{57}$ Justice Brennan

attempting to get that question before the Court. The likelihood of overruling similarly played a part in Abraham Lincoln's position on slavery, developed in connection with his opposition to the Court's decision in Dred Scott v. Sandford, 60 U.S. (19 How.) 393 (1857). See First Inaugural Address of Abraham Lincoln, in 6 MESSAges AND PAPERS OF THE PREsIdents 5 (J. Richardson ed. 1898).

${ }_{56}$ Justice Brennan's practice when rehearings in capital cases were sought showed that his position rested on a judgment about what is prudent. Although he routinely dissented from denials of review, he almost never dissented from denials of rehearings sought by capital defendants. My research assistants Nicole Tapay and Katya Lezin and I located approxirnately 100 cases in which rehearings were sought and denied. Justice Brennan dissented from the denial of rehearing in only two of them, and in one he was joined by Justices Stevens and Stewart, at least one of whom must have voted to deny review initially. See Morgan v. Georgia, 444 U.S. 976 (1979) (denying rehearing). (Morgan's death sentence later was vacated by a federal appellate court on habeas corpus. See Morgan v. Zant, 743 F.2d 775 (11th Cir. 1984). The most recent report of the case that $I$ have been able to locate is a 1987 decision by the Georgia Supreme Court affirming a decision below to allow certain evidence to be introduced at Morgan's resentencing.) I do not warrant the completeness of our search, which proved to be quite difficult even using computer search techniques.

When a rehearing is sought, the relevant law is not the Constitution but the internal operating procedures of the Supreme Court, which state that rehearings can be granted only if a member of the prior majority votes for a rehearing. For Brennan to dissent from a denial of rehearing ordinarily would amount to a repudiation of that rule, which is less important than the Constitution. As a matter of prudence, then, the particular rule of law involved being less important, it is less important to stand against its ordinary operation.

${ }^{57}$ The same concerns are expressed in Justice Brennan's opinion for the Court 
was untroubled by the fact, if it is one, that judicial review means that the courts will overturn decisions made by a majority of the people. The absence of countermajoritarian anxiety is built into majoritarian egalitarianism. When Justice Brennan expressed this theme in his jurisprudence, he claimed that it is superficial to contend that the courts are acting against the views of a majority. When they invalidate legislation, the courts are acting on behalf of a majority that has been unable to overcome some obstacles to the enactment of its views.

Putting the point this way may understate its scope as reflected in Justice Brennan's opinions. John Hart Ely's book Democracy and Distrust ${ }^{58}$ elaborated a theory of judicial review that makes judicial review a majoritarian enterprise. But, Ely's "distrust" is a far cry from the robust confidence that Justice Brennan expresses. For Ely, distrust has two faces. Sometimes we cannot trust majorities to act fairly; sometimes we cannot trust judges to discern what ought to be done. ${ }^{59}$ The first kind of distrust makes it essential to develop and justify judicial review; the second kind makes it essential to define the limits of judicial power.

Justice Brennan's confidence similarly has two faces, but they are precisely the reverse of Ely's. His approach to questions of equality has two parts. First, the Supreme Court will give the people of the United States what they really want (the majoritarian element). Second, the people of the United States really want equality (the egalitarian element). Under this approach, judicial review only superficially involves judicial action to overturn decisions made by a majority of the people; at a deeper level, for Justice Brennan, judicial review involves judicial enforcement of what the majority wants.

Justice Brennan believed that we can trust the people of the United States to make the right decision if they are given the chance, and that we can trust the judges to figure out how to give them that chance. Justice Brennan's majoritarian defense of judicial review echoes but transforms an earlier approach to the problem. Responding to the countermajoritarian difficulty of judicial review, some writers in the 1960s argued that judicial review might be

in Texas v. Johnson, $109 \mathrm{~S}$. Ct. 2533 (1989), the flag-burning case, whose calming tones are designed to tell readers that the prudent response to flag-burning is to renew their respect for the flag.

${ }_{58}^{58} \mathrm{~J}$. Ely, DEMOcRaCY AND Distrust: A Theory of Judicial REview (1980).

39 See id. at 103. 
understood as a technique of remanding a question for reconsideration by the people: an appeal from John drunk to John sober. ${ }^{60}$

In that form, the defense of judicial review was incomplete. Suppose, after the remand, the people decided that they really did want the statute that the Court had held unconstitutional. I can imagine that the Court would say, "Well, if that's what you really want, we'll let you do it. The statute is no longer unconstitutional, even though it was when we first considered the case. ${ }^{n 1}$ But, I suspect that it would respond more often: "We really meant it the first time around. ${ }^{n 2}$ Sober second-thought review, that is, does not look like judicial review as we have come to know it.

Justice Brennan's majoritarian egalitarianism, in contrast, does "justify" judicial review in its classic form. If he wanted, Justice Brennan could call judicial review a remand to the people for reconsideration, but he would be confident that, on reconsideration, the people would conclude that the statute at issue should not be reenacted. This is, of course, an extremely optimistic view of contemporary society.

As I suggested in discussing Frontiero, Justice Brennan's approach works to the degree that the judges are in tune with the real desires of the people of the country. ${ }^{63}$ At this point it is worth emphasizing the resonances of some of the words $I$ have used to characterize Justice Brennan's majoritarian egalitarianism. The key words are "anxiety" and "confidence." Justice Brennan rarely expressed the countermajoritarian anxiety that afflicted constitutional theory under the influence of Felix Frankfurter. He was not anxious about judicial review because he was confident in the judges, in the first instance, and in the people of the United States ultimately. These are, in the end, traits of character, and they are

${ }^{60}$ For an early presentation of the "remand" idea, see Bickel \& Wellington, Legislative Purpose and the Judicial Process: The Lincoln Mills Case, 71 HARV. L. REv. 1, 32-35 (1957) (noting some of the difficulties of this idea). For a recent presentation of the idea, see P. Dimond, The Supreme CourT AND Judicial ChOICE: THE Role of Provisional ReView in a Democracy (1989).

${ }^{61}$ Obviously, changes in the composition of the Court affect its ability to give this response easily. Yet, such changes do not seem to be what the "remand" theorists had in mind.

62 See, e.g., United States v. Eichman, 110 S. Ct. 2404 (1990) (holding the Flag Burning Act unconstitutional). I note, though, that the events associated with the flag-burning episode probably can be used to support whatever position one maintains about the constitutional order.

63 For a similar analysis, though with a more skeptical edge, see A. BICKEL, THE SUPREME COURT AND THE IDEA OF PROGRESS (1970). 
undeniably attractive. Justice Brennan became honored, I believe, not so much because he was right so often (though he was), but because he showed us that we wanted to be right. 
